\title{
Tasting freedom: Happiness, religion and economic transition
}

\author{
Orsolya Lelkes
}

\section{Contents}

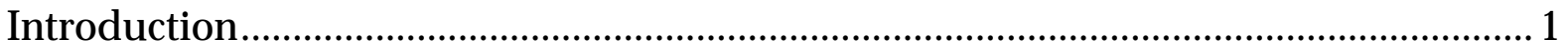

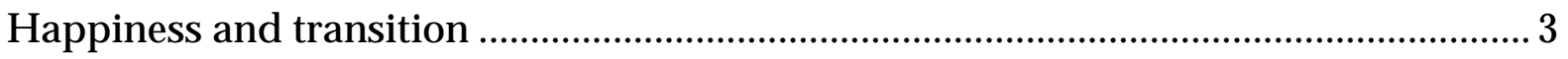

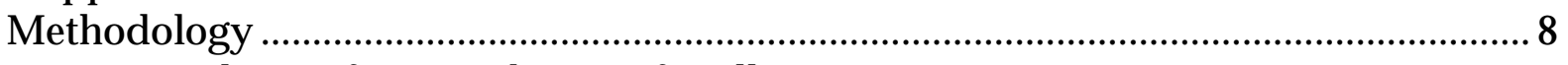

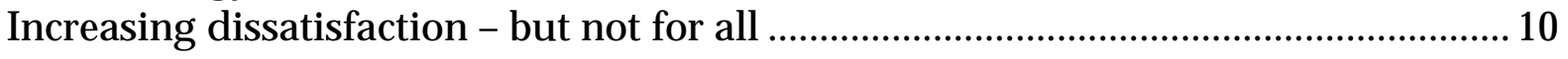

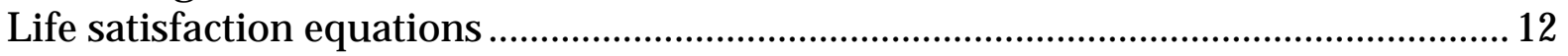

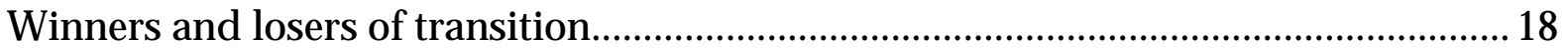

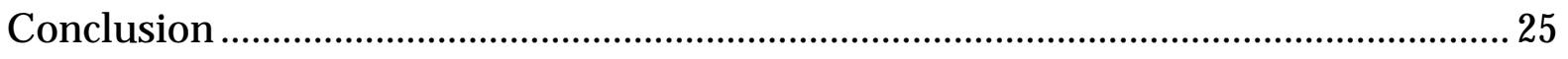

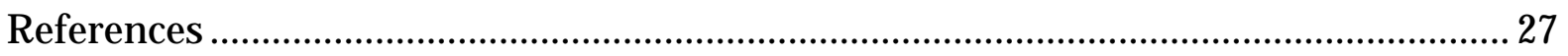

CASEpaper 59

August 2002
Centre for Analysis of Social Exclusion London School of Economics Houghton Street London WC2A 2EA CASE enquiries - tel: 02079556679 


\section{Centre for Analysis of Social Exclusion}

The ESRC Research Centre for Analysis of Social Exclusion (CASE) was established in October 1997 with funding from the Economic and Social Research Council. It is located within the Suntory and Toyota International Centres for Economics and Related Disciplines (STICERD) at the London School of Economics and Political Science, and benefits from support from STICERD. It is directed by Howard Glennerster, John Hills, Kathleen Kiernan, Julian Le Grand, Anne Power and Carol Propper.

Our Discussion Paper series is available free of charge. We also produce summaries of our research in CASEbriefs, and reports from various conferences and activities in CASEreports. To subscribe to the CASEpaper series, or for further information on the work of the Centre and our seminar series, please contact the Centre Administrator, Jane Dickson, on:

$\begin{array}{ll}\text { Telephone: } & \text { UK+20 } 79556679 \\ \text { Fax: } & \text { UK+20 } 79556951 \\ \text { Email: } & \text { j.dickson@lse.ac.uk } \\ \text { Web site: } & \text { http://sticerd.lse.ac.uk/Case }\end{array}$

(C) Orsolya Lelkes

All rights reserved. Short sections of text, not to exceed two paragraphs, may be quoted without explicit permission provided that full credit, including $($ notice, is given to the source. 


\section{Editorial Note and Acknowledgements}

Orsolya Lelkes was a PhD student at the LSE's Department of Social Policy and was member of the ESRC Research Centre for Analysis of Social Exclusion. The author is grateful to John Hills, Robert MacCulloch, Abigail McKnight, and seminar participants at the London School of Economics Research Laboratory for helpful comments. The author would also like to thank TÁRKI Social Research Centre, Budapest, for providing access to the datasets used in this paper. The author can be contacted at o.lelkes@lse.ac.uk.

\section{Abstract}

Economic transition lowered happiness on average, but did not affect all equally. This paper uses Hungarian survey data to study the impact of religion and economic transition on happiness. Religious involvement contributes positively to individuals' self-reported well-being. Controlling for personal characteristics of the respondents, money is a less important source of happiness for the religious. The impact of economic transition has varied greatly across different groups. The main winners from increasing economic freedom were the entrepreneurs. The religious were little affected by the changes. This implies that greater ideological freedom, measured by a greater social role of churches, may not influence happiness per se.

Keywords: happiness, economic transition, religion, entrepreneurs JEL classification: Z12, P36 


\section{Introduction}

Survey evidence suggests that the level of individual self-reported happiness in Central-Eastern Europe is much below than that of Western Europe (Table 1). The political isolation of Socialism seems to have been replaced by an "iron curtain" of unhappiness. Little is known either on the causes of this difference or on the determinants of subjective well-being in Eastern Europe. This paper provides new empirical evidence on the latter. It analyses the correlates of individual's subjective well-being, or 'experienced utility' in Hungary and how these were affected by economic change in the 1990s. The focus is on two particular groups which might be expected to be strongly influenced by different aspects of transition: the religious and the self-employed. The starting hypothesis is that increasing freedom in an ideological sense contributed to the happiness of the religious people, while increasing freedom in an economic sense benefited entrepreneurs. The paper also investigates whether religious orientation makes it easier to bear the shock of economic transition, in other words how personal ideology influences people's utility.

Blanchflower and Freeman find that people's attitudes have changed during economic transition (1997). Over the course of the early years of transition, the degree of inequality which people regarded as 'fair' increased. These findings refer to population as a whole, with no differentiation between specific groups, especially along ideological lines. There is some evidence that 'happiness functions' differ based upon ideological orientation. Alesina, Di Tella and MacCulloch (2001) show that in European countries aversion to inequality is concentrated among those individuals who define themselves leftist. Easterlin (2001) suggests that the determinants of happiness are not stable during economic change. If material norms increase in proportion to actual income, more income does not bring more happiness. The basis for such arguments is that one's utility from income or consumption depends on one's attitude towards material consumption. It follows that the transformation of an economic regime is expected to affect specific ideological groups differently. 
Table 1: Happiness across Europe

\begin{tabular}{|c|c|c|c|c|c|}
\hline $\begin{array}{l}\text { Western- } \\
\text { Europe }\end{array}$ & $\begin{array}{c}\% \\
\text { very happy }\end{array}$ & $\begin{array}{c}\% \\
\text { satisfied }\end{array}$ & $\begin{array}{l}\text { Central- } \\
\text { Eastern- } \\
\text { Europe }\end{array}$ & $\begin{array}{c}\% \\
\text { very happy }\end{array}$ & $\begin{array}{c}\% \\
\text { satisfied }\end{array}$ \\
\hline Iceland & 42 & 85 & Poland & 14 & 57 \\
\hline Ireland & 42 & 80 & Slovenia & 11 & 47 \\
\hline Netherlands & 40 & 85 & Hungary & 11 & 44 \\
\hline Switzerland & 38 & 86 & Croatia & 8 & \\
\hline Great-Britain & 38 & 74 & Bulgaria & 7 & 25 \\
\hline Belgium & 37 & 79 & Czech Rep. & 6 & 50 \\
\hline Denmark & 36 & 86 & Romania & 6 & 44 \\
\hline Sweden & 36 & 84 & Slovakia & 6 & \\
\hline Austria & 30 & 64 & & & \\
\hline Norway & 29 & 78 & CIS & & \\
\hline France & 23 & 59 & Russia & 6 & 32 \\
\hline Finland & 20 & 79 & Belarus & 5 & 33 \\
\hline Spain & 20 & 66 & Ukraine & 5 & \\
\hline Germany & 16 & 71 & Estonia & 4 & 45 \\
\hline Italy & 13 & 71 & Lithuania & 4 & 44 \\
\hline \multirow[t]{2}{*}{ Portugal } & 13 & 63 & Moldova & 4 & \\
\hline & & & Latvia & 3 & 40 \\
\hline
\end{tabular}

Sources: World Values Survey: 1996 (happiness) and 1990-93 (satisfaction) (World Database of Happiness; Inglehart, Basáñez and Menéndez Moreno 1998)

Happiness measure: 'Taking all things together, would you say you are very happy, quite happy, not very happy, or not at all happy?'

Life satisfaction measure: 'All things considered, how satisfied are you with your life as a whole these days?' Ten-point scale: $1=$ dissatisfied, and 10=satisfied; \% 'satisfied' - scores 7 to 10

It is shown below using data from Hungary in the 1990s that religion, measured as regular churchgoing, is positively associated with life satisfaction. People's religious involvement also suggests different "tastes": money is a weaker correlate of subjective well-being among the religious population. Religious affiliation seems to bring rather stable microeconometric well-being functions, which were hardly affected by the landslide of economic transition. These regularities, however, are only valid if religiosity is measured as attachment to a religious institution. There is no evidence for attitudinal difference based on faith, measured as personal spiritual beliefs. In sum, contrary to the starting hypothesis, the religious did not become happier as a result of increasing ideological freedom. Instead, religiosity was a stable positive associate of happiness, with a specific attitudinal pattern. 
Entrepreneurs, by contrast, seem to have benefited from the increasing economic freedom. Using survey data from the beginning and the end of the economic transition, it is shown below that controlling for income, educational attainment and other personal characteristics, individual entrepreneurs became more satisfied over time, thus they are clear-cut winners of the economic change from Socialism to Capitalism.

\section{Happiness and transition}

Little is known on happiness or on subjective well-being during Socialism. "The official ideology claimed that every, or almost every, member of the society was satisfied" (Andorka 1999, p.147). Recent surveys suggest, however, that there is a major difference in the level of subjective well-being across European countries (see Table 1). We may say, that there is a new iron curtain, an iron curtain of unhappiness, which separates a happier part of Europe from a much less happy one. There is a clear division line between most Western European nations and other countries of Europe. Further to this, Central-Europe, especially Poland, Hungary and Slovenia, may be distinguished from Eastern Europe, and the former Soviet Union (CIS). Interestingly, this happier part of Eastern Europe is most likely to join first the 'happy house' of the European Union.

This difference cannot be purely attributed to simple cultural differences of the notion of happiness. A similar 'iron curtain' seems to exist when using other measures, the Bradburn Affect-Balance Scale or satisfaction with life. While in most Western European countries over $2 / 3^{\text {rd }}$ of the population say they are satisfied, in Central-Eastern Europe this number is generally less than half. A similar division seems to exist when people are asked about recent positive and negative affects in their lives ${ }^{1}$ (own calculations based on the World Database of Happiness).

The causes of this division may go back to the Communist era, thus may be related to the differences between the political regimes or may be

1 The mean score for Hungarians was 0.86 in 1990, while it was 0.76 in Czechoslovakia, 0.71 in Romania, 0.33 in Russia, in contrast to e.g. 1.70 in Great Britain, 1.77 in Austria and 2.90 in Sweden (World Database of Happiness). This scale, however, has been criticised in the literature, for example for measuring only the simple occurrence of feelings, not their intensity of frequency. (For more see Diener 1984.) 
attributable to negative consequences of the transition process. The former view seems to be confirmed by Blanchflower and Freeman, who show that Hungarian workers were less satisfied with their jobs than Westerners, even after controlling for objective features of work-places (1997). In their view, this confirms that 'workers under communism are less satisfied than workers under capitalism' (p. 449). They also find that there was a prevailing 'attitudinal legacy' of Communism in the early years of transition. '[C]itizens of former communist countries evinced a greater desire for egalitarianism, less satisfaction with their jobs, and more support for strong trade unions and state intervention in the job market and economy than did Westerners' (p. 438). Andorka (1992), a Hungarian sociologist, claims that a grave dissatisfaction indicated a deep societal crisis of alienation and anomie, which may have ultimately been one of the major causes of the collapse of the political system itself.

The relative unhappiness in Eastern Europe is likely to be related to the negative consequences of the transition process. Economic transition has resulted in 'transformational recession' (Kornai 1994), falling national income, declining state redistribution, rising unemployment, inequality and poverty. All this has most likely contributed to growing unhappiness, provided the findings of the existing literature are relevant for this region of Europe as well. As Di Tella, MacCulloch and Oswald (2001) demonstrated for 12 European countries, inflation and unemployment are negatively correlated with self-reported well-being. Others have shown that there is a prevailing negative relationship within countries between unemployment, low income, inequality and happiness (e.g. Clark and Oswald 1994; Winkelmann and Winkelmann 1998; Alesina et al. 2001).

Hungary seems to provide a useful case study for the analysis of subjective well-being in Eastern Europe for several reasons. Firstly, the outstanding suicide rate of the country has for a long time indicated relatively grave psychological distress. According to recent figures, the suicide rate of males in Hungary is over four times as high as in the United Kingdom (WHO 2001). This rate, however, is not exceptional in Eastern Europe: Russia, Ukraine and the Baltic states report similar or somewhat higher figures. Secondly, Hungary seems to be appropriate to study the impact of transition. The country belongs to the group of transition economies which have largely recovered from the economic recession together with the Czech Republic, Poland, Slovakia and Slovenia. These countries suffered a major fall in their national incomes, mostly around $20 \%$, but by 1998 their GDPs had mostly returned to its 
pre-transition level. It thus seems useful to study the impact of economic transition in Hungary as a member of this group, well advanced in the transition process. The conclusions of this analysis, however, are expected to be mostly relevant for countries which may be called Central Europe, and might be rather different from other countries of Eastern Europe. The final reason is practical: Hungarian general household surveys include questions on subjective well-being (SWB).

Transition in Eastern Europe was not just about economic change, but also brought greater social and political freedom. The impact of these changes might be expected to vary between groups with different values. Religiosity, representing a certain value orientation and a resulting set of attitudes, is thus expected to influence people's experienced utility during economic change. Is this a realistic assumption? Religion influences economic behaviour, for example work activity, school attendance, and economically important social behaviour, such as marriage, fertility and social misbehaviour [see the review of Iannaccone (1998)]. Religious institutions encourage appropriate behaviour and employ various methods of social control. Hull and Bold (1995) find, using US data, that church membership discourages social misbehaviour by providing property rights enforcement. Freeman (1986) argues that the influence of churchgoing on economic behaviour is at least to some extent a causal impact. Religion was also shown to contribute positively to subjective wellbeing, including life satisfaction and personal happiness among people in the US (Ellison 1991). The author also finds that 'strong religious faith makes traumatic events easier to bear' (p. 90) The focus of Ellison's analysis is on the multifaceted relationship between religious activity and subjective well-being. The influence of religion on what makes people happy, however, is not discussed.

The collapse of the long-standing atheist regime brought increasing social influence for the churches, which does not seem to have been accompanied with a lasting religious revival in the country. Although the right to free practice of religion existed during socialism, there were numerous legal and administrative constraints which seriously limited the freedom of religion. In the new political system churches were given back much of their properties nationalized after the second world war, including many church schools. Previously banned religious orders became legalized again. Law enabled the establishment of new churches as well. All this suggests that there was an increase in the freedom of 
religion, including a gradual expansion of institutionalized religion as a whole.

Formal church affiliation is widely prevalent in the country, but stronger commitment as religious participation is only a minority feature. As data from 1994 shows, 3/4 of the population has some religious affiliation, and $18 \%$ attend services more than once a month (Need and Evans 2001, pp 236-7) $)^{2}$. Data from World Values Survey show that $23 \%$ of Hungarians attended a religious service at least once a month in 1991 (N=999, own calculations). This measure uses a somewhat broader definition of church attendance, thus these two figures appear to be consistent. Despite prevailing problems with such data in general, it seems clear that religious participation in Hungary is about on the same level as in Britain, and much greater than in Russia or in the Czech Republic. Church attendance of Hungarians is, however, much below that of the Polish, the Irish and that of people in the US. The surveys used in this paper (see below) show that 20 and $19 \%$ of the people attended a religious service at least once a month in 1992 and 1998, respectively. Less conservative measures from the same dataset show a significant social role of religion. $90-91 \%$ of the people have been registered with a religious denomination at their birth, and only around 5\% claim themselves to be atheists. The largest church is the Catholic, with over $2 / 3$ of the population, followed by the Calvinist, where $18-19 \%$ is registered, and the Lutheran church, with 3-4\%.

The collapse of Communism and more openness to the secularised Europe did not bring major religious revival in the country. There was no significant rise in the ratio of churchgoers during the 1990s. There was, however, a change in the age structure of the religious, with a rising ratio of young adults. The surveys used here indicate that people between the age of 17 and 30 have become increasingly religious. By $199813.6 \%$ participated in religious activities, in contrast to $11.6 \%$ in 1992. At the same time, however, religious involvement declined among the older age groups, especially those between 50 and 62 years. Tomka and Harcsa (1994), studying long term trends of religious activities up to

$2 \mathrm{~N}=1307$. The survey data are part of the ESRC funded research programme on Eastern Europe. The authors also warn of the inadequacy of data on religiosity, both for international comparison and also for observing the changes in religiosity over time (Need and Evans 2001). For this reason, it appears difficult to test the hypothesis of 'religious revival' in Eastern European countries. 
1992-93, find no signs of major restructuring except at the time of the genocide of World War II. Analysing the social pattern of churchgoers they show that their ratio is particularly high among low skilled agricultural workers. Interestingly, among the 'intelligentsia', both the ratios of churchgoers and that of conscious atheists are outstanding. Similarly, others also found positive relationship between education and church attendance in Hungary, using multivariate regression (Need and Evans 2001). This appears to be a distinct feature of religiosity in Hungary, since this relationship was shown to be negative in most other Eastern European countries (p. 240, Table V).

A further aspect of transition was increasing economic freedom, greatly affecting those endowed with an entrepreneurial spirit. Capitalism did not create entrepreneurship in Hungary, but brought more favourable external conditions. Entrepreneurs already existed during Socialism. Similar to other countries of Eastern Europe, the rural population 'lived in two worlds', combining 'work for wages and salaries for the government with part-time family agricultural production' (Szelenyi and Manchin 1988, p.5). Beyond this, the Hungarian state was particularly liberal and enabled the evolution of a significant private sector from the mid 1980s, including small family businesses, and selfemployed, freelance individuals. The transition from Socialism to Capitalism brought profound change in property rights and raised a new class of corporate entrepreneurs. The evolution of large-scale entrepreneurs, characteristic of Western countries, however, is still at an early stage (Róbert 2001).

Beyond increasing ideological and economic freedom, the transition process also had undesirable economic consequences for the majority of the population. Firstly, there was a major decline in both national income and household income. 'Transformational recession' brought a major fall of GDP: its figure was lowest in 1993, when it was $18 \%$ less then its 1989 level. GDP reached its pre-transition level of 1989 only in 2000. Between the two survey dates used here (1991/92 and 1997/98) there was a minor fall, the GDP being already rather low at the start, followed by a recovery of about $8 \%$. Household incomes followed the decline of total output with delay, and were their lowest in 1996, when they were 16\% lower than their 1990 level. During the period examined here, there was over a 10\% decline in disposable (after tax and benefit) household incomes. Inflation, although high relative to recent Western European levels, was not a grave problem in the country, in contrast to 
numerous Eastern-European countries: it peaked at 33.4\% in 1990. In the period analysed here it declined from $32.9 \%$ to $17.9 \%$.

The metamorphosis of the labour market brought unemployment, a new phenomenon, and a drop in the level of employment, but also offered increasing opportunities for the self-employed and the highly skilled. The decline in the level of employment in Hungary approached 30\%, which is outstanding in the whole of the Central-Eastern Europe (Economic Commission for Europe 2000). The occurrence of such a decline, and the appearance of unemployment seem to be inherent parts of the transition process and are widely discussed in the academic literature. Unemployment was an entirely new phenomenon in its 'Capitalist' form, fundamentally different from 'underemployment', a familiar phenomenon for most East-Europeans. At the same time the highly skilled benefited from increasing premium for skills on the labour market. A new window of opportunity opened for entrepreneurs as a result of deregulation, and also that of price and trade liberalisation. The position of entrepreneurs is a second main focus of the analysis below.

\section{Methodology}

Two nationally representative household surveys are used, from an early and a later point in the transition process. The first survey investigates the period between April 1991 and March 1992. The later survey refers to the period between April 1997 and March 1998. The samples cover individuals above 16 years, and include 5365 observations in 1992 and 3802 in 1998. The measure of subjective well-being used here as dependent variable is life satisfaction, based on the following question: 'How satisfied you are with your life so far, the course of your life?' Respondents are given a choice of scores from 0 to 10, where 0 stands for 'not satisfied at all', and 10 for 'fully satisfied'. Notably, both of the income variables used in the analysis are aggregated from detailed survey questions, thus are more likely to be reliable than single question inquiries.

In the first part of the analysis multivariate regression is used to analyse the patterns of subjective well-being across population groups in 1992 and 1998. The regression models incorporated sampling weights for the correction of sampling design (1992) and of sample fit (1998). The second part of the analysis uses a pooled dataset, which may be called pooled cross-sectional time series, consisting of a pooled sample of the two 
surveys. This joint dataset consists of 9167 observations. Since the sample sizes in 1992 and 1998 were not equal, a special weight variable has been created in order to generate equal sub-samples. In this way, the probability of an observation to be included in the pooled sample is the same irrespective of whether it originally belongs to the 1992 or the 1998 sub-sample.

Microeconometric well-being functions are estimated separately for both 1992 and 1998, which take the form

$$
\begin{aligned}
& \text { HAPPINESS }_{\mathrm{it}}=\mathrm{f}\left(\mathrm{RELIGION}_{\mathrm{it}} \text { AGE }_{\mathrm{it} t} \text { INCOME }_{\mathrm{it},}\right. \\
& \text { LABOURMARKETST } \left._{\mathrm{it},} \text { EDUCATION }_{\mathrm{it},}, X_{\mathrm{it}}\right)
\end{aligned}
$$

HAPPINESS $_{\text {it }}$ is satisfaction with life for individual $i$ in year $t$, RELIGION $_{\mathrm{it},}$ is participation in a religious service at least once a month, $\mathrm{AGE}_{\mathrm{it}}$ is the age of individual i with 5 categories, $\mathrm{INCOME}_{\mathrm{it}}$ is the log of real annual income, where income is disposable equalised household income (after taxes and transfers) with an equivalence scale of $\mathrm{e}=0.73$, LABOURMARKETST $_{\text {it }}$ indicates the labour market status of individual $i$, EDUCATION $_{i t}$ is a categorical variable for education, $X$ is a vector of other personal characteristics.

The impact of change over time is also studied, using a linear regression.

$$
\text { HAPPINESS }_{\text {POOLEDi }}=\mathrm{h}\left(\mathrm{Y}_{\mathrm{i}}, \mathrm{YEAR} \mathrm{Y}_{\mathrm{i}}^{*} \mathrm{YEAR}\right)
$$

HAPPINESS $_{\text {POOLEDi }}$ stands for satisfaction with life in the pooled dataset over 1992 and 1998 for individual it, and YEAR is a dummy, which takes a value of one in 1998. $\mathrm{Y}$ is a vector of the variables of interest, which is identical to the set of variables used in equation (1). In this part of the analysis an additional income variable is also used beyond equivalised household income: total personal income. This includes annual earnings, fringe benefits and cash state transfers, after taxes. This additional income variable enables a sensitivity analysis of the results.

Firstly a weighted least squares equation is estimated. This means that I treat the dependent variable as a continuous variable. This is followed by a weighted ordered logit model, which treats the dependent variable as discrete and exploits the ranking information. Throughout the paper a robust estimator of variance is used in order to account for heteroscedasticity. 
Disability pensioner status was included as a specific variable reflecting the Hungarian context. Disability pensions are paid to working age individuals who are classified as unable to work due to ill health or disability. The number of disability pensioners has substantially increased during economic transition. This was a preferred way of 'exit' from the labour market compared to unemployment for many people, allowed by permissive legislation.

Subjective well-being, SWB for simplicity's sake, is used interchangeably with self-reported well-being, life satisfaction, happiness or experienced utility. Life satisfaction is just one of various measures of subjective wellbeing. 'Experienced utility' has been used recently as an alternative to utility as a revealed choice (Kahneman, Wakker and Sarin 1997). Selfreported happiness or life satisfaction are reliable measures of experienced utility, as demonstrated in the psychological literature and in the emerging 'economics of happiness' (see e.g. the reviews of Veenhoven 1996; Diener, Suh, Lucas and Smith 1999). The current analysis is based on the specific survey measure of life satisfaction described earlier. Religious involvement, as mentioned before, is a measure of participation in a religious worship at least once a month. This time limit allows the proportionately representative inclusion of Protestants as well, where regular churchgoing is less frequent than for the Catholic majority. I define attitudes here as personal beliefs and opinions, such as those referring to how much utility an individual has from material consumption. Religious belief, beyond relating to faith and worship, has a value orientation and a resulting set of attitudes. The current study focuses on those attitudinal attributes of religious involvement, which are related to the transforming economy.

\section{Increasing dissatisfaction - but not for all}

Life satisfaction declined over economic transition. At the later point of transition people's average satisfaction score was significantly smaller than at the early phase (see Table 2). This implies that the increase of freedom, including greater opportunities to voice political preferences, which were shown to contribute to happiness elsewhere (Frey and Stutzer 2000), had less impact than the negative economic consequences of transition. There is considerable variation by age, religious involvement and labour market status. Age has a U-shaped relationship with life satisfaction, the young being the most contented (Figure 1). 
Satisfaction is the lowest in late middle age, between 40 and 49 years ${ }^{3}$. Those who are religious report significantly higher levels of well-being at both points in time, as indicated by Table 2 . There is no significant difference between believers and non-believers, defined on the basis of personal faith. Denominational differences between Catholic and Calvinist groups, the two major churches in the country, are not significant. With regards to changes over time, the decline of satisfaction was prevalent among both the religious and the non-religious population.

\section{Figure 1: Relationship between age and life satisfaction in Hungary}

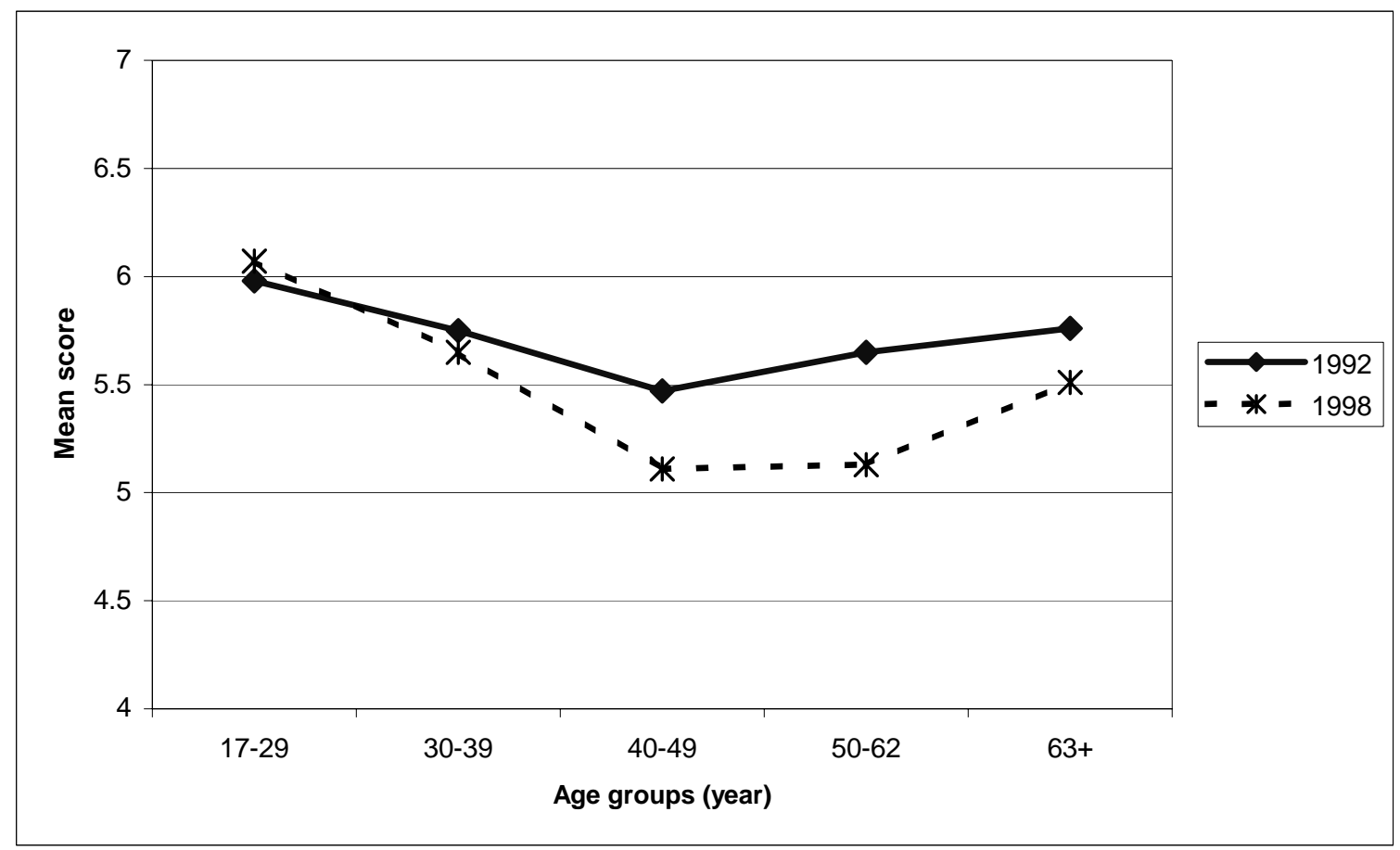

There is a systematic difference between the life satisfaction of various labour market groups (see Table 2). The unemployed are the least satisfied. Students are the other extreme, being the most contented. Disability pensioners report much lower levels of SWB than old age pensioners, but higher levels than the unemployed. This specific group of pensioners thus seems to show distinct characteristics from that of old age pensioners. The difference between employees and self-employed is not significant in 1992, but it has become so by 1998. The self-employed

3 Similarly, the minimum of SWB is around the age of forty in Britain and the US, as reported by Blanchflower and Oswald (2000, pp. 11, 14). 
became a distinct group within the employed over the transition, with markedly higher SWB.

Table 2. Life satisfaction by religion and labour market status in Hungary

\begin{tabular}{lcc|cc}
\hline \hline & \multicolumn{2}{c|}{$\mathbf{1 9 9 1 / 9 2}$} & \multicolumn{2}{c}{$\mathbf{1 9 9 7 / 9 8}$} \\
\cline { 2 - 5 } & Average score & $\mathbf{N}$ & Average score & $\mathbf{~ N}$ \\
\hline All & 5.74 & 5365 & 5.51 & 3802 \\
Religion: & & & & \\
Religious & 6.01 & 1029 & 5.82 & 750 \\
Non-religious & 5.68 & 4296 & 5.44 & 3040 \\
Religious, Catholic & 5.73 & 3647 & 5.46 & 2752 \\
Religious, Calvinist & 5.66 & 1160 & 5.54 & 682 \\
Believer & 5.75 & 2371 & 5.55 & 1678 \\
Non-believer & 5.72 & 2814 & 5.44 & 1789 \\
Employment status: & & & & \\
Employee & 5.97 & 2584 & 5.83 & 1379 \\
Self-employed & 5.85 & 208 & 6.35 & 134 \\
Unemployed & 4.24 & 224 & 4.03 & 151 \\
Disability pensioner & 4.80 & 283 & 4.57 & 314 \\
Pensioner & 5.69 & 1393 & 5.28 & 1232 \\
Student & 7.13 & 320 & 6.84 & 228 \\
Other inactive & 4.99 & 352 & 5.13 & 360 \\
\hline \hline
\end{tabular}

\section{Life satisfaction equations}

Religious involvement is positively correlated with life satisfaction. The effect is prevalent at both the beginning and the end of the transition process, both in the OLS and the ordered logit regressions. The size of the coefficient remains about the same over time. Participation in religious activities explains $5-5.6 \%$ of the variation in subjective wellbeing (see Table 3). The effect is modest: religiosity increases the probability of being fully satisfied by $2.6 \%$ (1.5\%) in 1992 (1998) (see the third column in Table 4). Similar positive correlations between religion, particularly churchgoing, and SWB has been found in a series of Western European countries and the United States [see the review of Argyle (1999)]. There is no such pattern if 'faith' is used as an explanatory variable in this model. The possible reason is that it is the institutional aspect of religious involvement that enhances the 
development of specific norms, different from those prevailing in the society at large. We may also assume that people derive satisfaction from the activity of participation itself. In any of these two cases, we could expect a systematic difference in the in the determinants of happiness for the religious and non-religious population.

The coefficient for the self-employed is not significant in either year, in contrast to earlier cross-tabulations in Table 2, which indicated that selfemployed were markedly more satisfied than employees in 1998. This may be attributable to the fact that entrepreneurs as a group are rather stratified, where some individuals prosper, while others fail to succeed and exit self-employment soon (Róbert and Bukodi 2001). Many of this latter group has chosen self-employment as a route out of joblessness. Also, the development of the larger private businesses, is at a rather early stage in Hungary compared to Western countries, although the proportion of entrepreneurs in total is on a similar level (Róbert 2001).

I have tested whether there is any difference between entrepreneurs who have one or more employees and those with none. The results, however, are just indicative due to the small number of observations in the former group of 'larger businesses' (only 35 and 34 entrepreneurs in the two years, respectively), and therefore are not presented here in detail. This group seems to be particularly strongly affected by the economic consequences of transition. They had significantly lower level of life satisfaction (a mean score of 5.5) than employees or sole entrepreneurs in 1992, at the time when transformational recession and inflation soared. By 1998, with an expanding economy, where GDP was about to reach its pre-transition level, the satisfaction of 'larger businesses' increased to an outstanding figure, to 7.1, in contrast to the score of 5.8 of employees. The multivariate regressions with the same specification as Table 3, indicate similar results as the simple crosstabulations. Entrepreneurs with at least one employee were significantly less satisfied with their lives in 1992 than employees, ceteris paribus. By 1998, they became significantly more satisfied than the reference group. The coefficient in both years is significant at 5\% level. The group of 'larger businesses' thus seems to be particularly affected by changes in the economic environment. 


\section{Table 3: Satisfaction with life in Hungary, 1991/92 and 1997/98 - weighted least squares}

\begin{tabular}{|c|c|c|c|c|c|c|}
\hline & \multicolumn{3}{|c|}{ 1991/92 } & \multicolumn{3}{|c|}{$1997 / 98$} \\
\hline & Coef. & Std. Err & Beta & Coef. & Std. Err & Beta \\
\hline Religious & $0.379^{* * *}$ & 0.099 & 0.056 & $0.332^{* * *}$ & 0.102 & 0.050 \\
\hline Income $(\ln )$ & $0.975^{* * *}$ & 0.094 & 0.170 & $0.741^{* * *}$ & 0.095 & 0.152 \\
\hline Self-employed & -0.282 & 0.199 & -0.019 & 0.230 & 0.202 & 0.016 \\
\hline Unemployed & $-1.020^{* * *}$ & 0.213 & -0.077 & $-0.983^{* * *}$ & 0.243 & -0.079 \\
\hline Disability pensioner & $-0.791^{* * *}$ & 0.197 & -0.066 & $-0.648^{* * *}$ & 0.163 & -0.069 \\
\hline Pensioner & -0.213 & 0.158 & -0.034 & $-0.455^{* * *}$ & 0.155 & -0.079 \\
\hline Student & $1.809^{* * *}$ & 0.177 & 0.154 & $1.466^{* * *}$ & 0.186 & 0.149 \\
\hline Other inactive & $-0.484^{* * *}$ & 0.167 & -0.047 & -0.250 & 0.166 & -0.030 \\
\hline Age:17-29 yrs & $0.481^{* * *}$ & 0.148 & 0.074 & $0.867^{* * *}$ & 0.169 & 0.143 \\
\hline Age: $30-39$ yrs & 0.127 & 0.138 & 0.018 & $0.456^{* * *}$ & 0.146 & 0.064 \\
\hline Age: $50-62$ yrs & $0.476^{* * *}$ & 0.142 & 0.071 & $0.244^{*}$ & 0.139 & 0.039 \\
\hline Age: 63 and more & $1.009^{* * *}$ & 0.185 & 0.152 & $0.960^{* * *}$ & 0.184 & 0.152 \\
\hline Vocational training & $0.370^{* * *}$ & 0.113 & 0.058 & $0.416^{* * *}$ & 0.114 & 0.070 \\
\hline Secondary education & $0.624^{* * *}$ & 0.105 & 0.095 & $0.923^{* * *}$ & 0.111 & 0.146 \\
\hline Higher education & $1.030^{* * *}$ & 0.136 & 0.113 & $1.351^{* * *}$ & 0.152 & 0.157 \\
\hline Female & $0.234^{* * *}$ & 0.080 & 0.043 & 0.049 & 0.086 & 0.009 \\
\hline Ethnicity (Gypsy) & $-0.440^{*}$ & 0.227 & -0.032 & $-0.736^{* * *}$ & 0.239 & -0.059 \\
\hline Budapest & -0.070 & 0.078 & -0.010 & $-0.186^{*}$ & 0.109 & -0.027 \\
\hline Married & $0.786^{* * *}$ & 0.148 & 0.140 & $0.789^{* * *}$ & 0.157 & 0.151 \\
\hline Divorced & $-0.590^{* * *}$ & 0.206 & -0.055 & $-0.481^{* *}$ & 0.204 & -0.050 \\
\hline Widow/er & -0.179 & 0.205 & -0.021 & 0.333 & 0.208 & 0.044 \\
\hline 1 child & $-0.600^{* * *}$ & 0.204 & -0.107 & -0.286 & 0.245 & -0.052 \\
\hline 2 children & $-0.562^{* * *}$ & 0.200 & -0.081 & -0.279 & 0.246 & -0.041 \\
\hline 3 or more children & -0.229 & 0.201 & -0.030 & -0.106 & 0.256 & -0.013 \\
\hline Constant & $-6.607^{* * *}$ & 1.135 & & $-4.078^{* * *}$ & 1.105 & 0 \\
\hline $\mathrm{R}^{2}$ & 0.139 & & & 0.167 & & \\
\hline F ratio & 33.91 & & & 30.93 & & \\
\hline Observations & 5202 & & & 3730 & & \\
\hline
\end{tabular}

Notes: Dependent variable: level of satisfaction on an eleven-point scale. Definition of income: equivalised household income. (The models have been corrected for heteroscedasticity. The so-called Huber/White or sandwich estimator of variance was used. This alternative variance estimator produces consistent standard errors if the residuals are not identically distributed. The standard errors presented above are therefore robust standard errors.) * denotes significance at $10 \%$ level, ${ }^{* *}$ denotes significance at $5 \%$ level, *** denotes significance at 1\% level Reference categories: 40-49 years, elementary education or below, employee, single, no children. 
Why does entrepreneurship seem to have a positive effect beyond that of higher earnings? Entrepreneurship brings higher job satisfaction, and a large number of people would prefer to be self-employed, both in Eastern and Western Europe (Blanchflower, Oswald and Stutzer 2001). The survey data used here also shows that the job satisfaction of selfemployed as a whole and especially that of self-employed with larger businesses greatly surpasses that of employees in 1998, by the time the new economic system has consolidated. Possible explanation for this is given in the classic study of Schumpeter, who describes the motivations of the entrepreneur. What drives the entrepreneur, 'are primarily three things: (1) the dream and the will to found a private kingdom, usually, [...], also a dynasty'; (2) 'the will to conquer: [...], to succeed for the sake, not of the fruits of success, but of success itself'; and (3) 'the joy of creating' (1934, p. 93). This implies that money is not the sole and ultimate motivation of an entrepreneur. The relative satisfaction of entrepreneurs with employees even after controlling for income appears to supports this. A possible further element of this list could be 'to have control over one's life'. This could explain why in an environment of great future risks in the early 1990s larger businesses were dissatisfied with their life in general.

Interestingly, students are very satisfied, over and above the positive effect of being young. As Table 4 shows being a student increases the probability of being fully satisfied by 17\% in 1992 and 10.1\% in 1998, compared to employees. The relative advantage of students in terms of life satisfaction is bigger than the disadvantage of the unemployed. For the latter group, the probability of being fully satisfied falls from only 5\% to 3.5\% between 1992 and 1998. Although a similar pattern occurs in European nations - being at school has a significant and positive impact on happiness - the effect is smaller (Alesina et al. 2001). The reason for the contentment of students might be partly attributable to discounted future incomes. This seems to be supported by the regularity that education has increasing returns in terms of subjective well-being. Those with higher education have the highest level of satisfaction, even after controlling for labour market status and household income. Since the labour market in Hungary in general rewards educational attainment by premiums for skills, it is plausible to assume that this relative satisfaction of the well educated has a lot to do with their earnings potential. 


\section{Table 4: Satisfaction with life in Hungary, 1991/92 and 1997/98 - weighted ordered logit}

\begin{tabular}{|c|c|c|c|c|c|c|}
\hline & \multicolumn{3}{|c|}{1992} & \multicolumn{3}{|c|}{1998} \\
\hline & Coef. & Std. Err & $\begin{array}{c}\text { Marginal } \\
\text { effect } \\
\text { (score 10) }\end{array}$ & Coef. & $\begin{array}{l}\text { Std. } \\
\text { Err }\end{array}$ & $\begin{array}{c}\text { Marginal } \\
\text { effect } \\
\text { (score 10) }\end{array}$ \\
\hline Religious & $0.266^{* * *}$ & 0.070 & 0.026 & $0.226^{* * *}$ & 0.077 & 0.015 \\
\hline Income $(\ln )$ & $0.690^{* * *}$ & 0.067 & 0.063 & $0.570^{* * *}$ & 0.079 & 0.035 \\
\hline Self-employed & -0.198 & 0.139 & -0.017 & 0.194 & 0.154 & 0.013 \\
\hline Unemployed & $-0.726^{* * *}$ & 0.150 & -0.051 & $-0.771^{* * *}$ & 0.183 & -0.035 \\
\hline Disability pensioner & $-0.517^{* * *}$ & 0.139 & -0.039 & $-0.453^{* * *}$ & 0.121 & -0.023 \\
\hline Pensioner & -0.125 & 0.113 & -0.011 & $-0.301^{* * *}$ & 0.116 & -0.017 \\
\hline Student & $1.234^{* * *}$ & 0.123 & 0.170 & $1.087^{* * *}$ & 0.142 & 0.101 \\
\hline Other inactive & $-0.314^{* * *}$ & 0.119 & -0.026 & -0.183 & 0.130 & -0.010 \\
\hline Age: $17-29$ yrs & $0.331^{* * *}$ & 0.101 & 0.032 & $0.659^{* * *}$ & 0.129 & 0.048 \\
\hline Age: $30-39$ yrs & 0.067 & 0.094 & 0.006 & $0.345^{* * *}$ & 0.108 & 0.023 \\
\hline Age: $50-62$ yrs & $0.310^{* * *}$ & 0.098 & 0.030 & 0.168 & 0.103 & 0.011 \\
\hline Age: 63 and more & $0.699 * * *$ & 0.132 & 0.075 & $0.693^{* * *}$ & 0.137 & 0.049 \\
\hline Vocational training & $0.264^{* * *}$ & 0.081 & 0.025 & $0.297^{* * *}$ & 0.086 & 0.019 \\
\hline Secondary education & $0.439 * * *$ & 0.075 & 0.044 & $0.709^{* * *}$ & 0.086 & 0.051 \\
\hline Higher education & $0.716^{* * *}$ & 0.098 & 0.081 & $1.058^{* * *}$ & 0.119 & 0.093 \\
\hline Female & $0.163^{* * *}$ & 0.056 & 0.015 & 0.045 & 0.065 & 0.003 \\
\hline Ethnicity (Gypsy) & $-0.291^{*}$ & 0.159 & -0.024 & $-0.514^{* * *}$ & 0.188 & -0.025 \\
\hline Budapest & -0.056 & 0.054 & -0.005 & $-0.163^{*}$ & 0.083 & -0.009 \\
\hline Married & $0.497^{* * *}$ & 0.103 & 0.043 & $0.575^{* * *}$ & 0.116 & 0.034 \\
\hline Divorced & $-0.438^{* * *}$ & 0.145 & -0.034 & $-0.364^{* *}$ & 0.150 & -0.019 \\
\hline Widow/er & -0.185 & 0.146 & -0.016 & 0.234 & 0.156 & 0.015 \\
\hline 1 child & $-0.388^{* * *}$ & 0.141 & -0.037 & -0.212 & 0.180 & -0.013 \\
\hline 2 children & $-0.331^{* *}$ & 0.138 & -0.028 & -0.198 & 0.183 & -0.011 \\
\hline 3 or more children & -0.106 & 0.138 & -0.009 & -0.097 & 0.192 & -0.006 \\
\hline Prob>chi2 & 0.0000 & & & 0.0000 & & \\
\hline Observations & 5202 & & & 3730 & & \\
\hline
\end{tabular}

Notes: Dependent variable: level of satisfaction on an eleven-point scale. Definition of income: equivalised household income. Corrected for heteroscedasticity, using white estimator for variance. ${ }^{*}$ denotes significance at $10 \%$ level, ${ }^{* *}$ denotes significance at $5 \%$ level, ${ }^{* * *}$ denotes significance at $1 \%$ level

Reference categories: 40-49 years, elementary education or below, employee, single, no children. 
Income and labour market status are major correlates of subjective wellbeing. As expected, income is positively, while unemployment, and disability pensioner status, the other form of withdrawal from the labour market, are negatively correlated with satisfaction, controlling for a series of demographic characteristics. These finding are similar to the recurring patterns of happiness across Western European countries. In most countries, individuals with high incomes say themselves happier than those who have less (for a recent survey see: Diener and Oishi 2000). Unemployment is a major cause of unhappiness. Winkelmann et al. (1998) using German panel data find that unemployment has high non-pecuniary costs, which indicate the existence of psychological costs beyond the sheer loss of income.

The impact of age is stronger than that of religion, but appears to be less stable over time. The previously observed U-shaped relationship seems to largely prevail, even after controlling for a series of economic and demographic characteristics. This finding is similar to the pattern found to occur in most Western European countries (e.g. Di Tella, MacCulloch and Oswald 1999). The young adults, those below 29 years, and the elderly, those over 63, are consistently significantly more satisfied than the reference category of those between 40 and 49 . Interestingly, there is an increase in the coefficient of the youngest age group, their contentment grew over the period of the consolidation of the new economic system. The reason may be that the young were consistently the most supportive of the new market system, as the New Democracies Barometer Survey series show (e.g. Rose and Haerpfer 1998).

Further regularities in the variation of subjective well-being indicate that divorce is negatively correlated, while marriage, and education level is positively correlated with life satisfaction. These findings are similar to those of the empirical literature on other countries (recent reviews: Argyle 1999; Diener et al. 1999). Notably, there was a major drop in the SWB of women and the Romany (Gypsy) ethnicity group between 1992 and 1998. Women were more hit by the fall of employment on the labour market than men and probably they were particularly affected by the declining state support for child care. The Gypsy population has an outstanding ratio of joblessness and inactivity, which may be a source of social disadvantage in various ways. Falling SWB may also indicate a decline of tolerance towards Gypsies.

We may speak of causal effects in case of those variables, which are mostly beyond an individual's choice. Thus, personal characteristics, 
such as age, sex, and ethnicity cause varying levels of satisfaction. Being young is a major source of satisfaction. We can say without hesitation that it is youth, which causes happiness, since (for some, unfortunately) choosing our age depending on our attitudes is not possible. The causal effect of religion is less clear-cut. It may also be possible that those who are happy in the new economic system are more likely to become religious, or that people with a certain disposition are more likely to be both happy and religious.

Referring to the first objection, it seems that the overall majority of those who are churchgoers have been doing so for a long time. The survey data show that $90.5 \%$ of those who are practising religion claim that they have always been religious. 5.4\% says in 1992 that they have become religious only recently, which rose to $7.4 \%$ by 1998 . This difference, however, is not significant at the $10 \%$ level. In general, there has been no significant change neither in the total number of those practicing religion nor in the number of new believers. In the following analysis I have accounted for the possible impact of 'newcomers' on the results, and estimated a separate model with their exclusion (see Table 6). It is probably not possible to exclude entirely the second reservation, that of spurious correlation. The main counter to this is that experienced utility is to a large extent the function of recent life events. Religiosity, in contrast, is mostly a longer-term characteristic, which includes various time-tested ways of socialisation and institutional control. The choice of the variable for religiosity as participation in religious services captures this institutional element, thus seems to seize causality at least to some extent.

\section{Winners and losers of transition}

This section specifically assesses changes in the correlates of happiness over time. How has transition affected the life satisfaction of specific population groups? Using self-reported well-being we can also seek to answer the question: who were the winners and the losers of the economic transition? Who benefited from increasing freedom? How does religion modify the observed general patterns of SWB? Is there a specific pattern of happiness along ideological lines? 
Increasing economic freedom: entrepreneurship, income and utility Increasing economic freedom, as expected, benefited those who could use this freedom the most: the entrepreneurs. Entrepreneurship has become more positively associated with life satisfaction over time, even after controlling for income, education, age and a series of other personal characteristics. This finding holds irrespective of the definition of income in the model, as Table 5 shows using both equivalised household income and personal income. Entrepreneurs are the only labour market group, which seem to have improved their situation in the observed period, thus they may be called the winners of the transition process.

The experienced utility of entrepreneurs thus increased over the 1990s, ceteris paribus. In the light of this result it appears somewhat puzzling that self-employed as a whole were not significantly more satisfied than employees in 1998, controlling for their comparatively higher income level and other personal characteristics (see earlier results presented in Tables 3 and 4). Entrepreneurs, as mentioned before, are a rather stratified group, which may explain the lack of such effect for the group as a whole. As mentioned before, there is tentative evidence for the higher satisfaction of entrepreneurs with larger businesses, controlling for income and other personal characteristics. Consistently with the results presented in Table 5 for all entrepreneurs, entrepreneurs with employees have also improved their relative position. The coefficient indicating the interaction effect for 'larger businesses' is positive and significant at $1 \%$ level in a model with a similar specification as the one presented in Table 5, including two specific subgroups of entrepreneurs. Due to the small number of cases, however, these results have to be regarded provisional and are not presented here.

Education has become somewhat more important over time. The interaction effects of secondary and higher education are positive and significant (Table 5). In a shift to market economy, there seems to be a strengthening relationship between individuals' human capital and experienced utility. 
Table 5: Effect of transition on happiness in Hungary, 1991-1998

\begin{tabular}{|c|c|c|c|c|}
\hline & I & & II & \\
\hline & Coef. & Std. Err. & Coef. & Std. Err. \\
\hline Religious & $0.379^{* * *}$ & 0.099 & $0.372^{* * *}$ & 0.100 \\
\hline Religious*year & -0.047 & 0.142 & -0.024 & 0.143 \\
\hline Self-employed*year & $0.512^{*}$ & 0.283 & $0.486^{*}$ & 0.284 \\
\hline Equivalised household income (ln) & $0.975^{* * *}$ & 0.094 & & \\
\hline Personal income (ln) & & & $0.368^{* * *}$ & 0.071 \\
\hline Unemployed & $-1.020^{* * *}$ & 0.213 & $-0.971^{* * *}$ & 0.218 \\
\hline Disability pensioner & $-0.791^{* * *}$ & 0.197 & $-0.863^{* * *}$ & 0.200 \\
\hline Pensioner & -0.212 & 0.158 & $-0.296^{*}$ & 0.160 \\
\hline Self-employed & -0.282 & 0.199 & -0.181 & 0.198 \\
\hline Student & $1.809^{* * *}$ & 0.177 & $2.562^{* * *}$ & 0.237 \\
\hline Other inactive & $-0.484^{* * *}$ & 0.167 & $-0.373^{*}$ & 0.194 \\
\hline Vocational training & $0.370^{* * *}$ & 0.113 & $0.382^{* * *}$ & 0.115 \\
\hline Secondary education & $0.624^{* * *}$ & 0.105 & $0.705^{* * *}$ & 0.107 \\
\hline Higher education & $1.030^{* * *}$ & 0.136 & $1.175^{* * * *}$ & 0.139 \\
\hline Age $17-29$ yrs & $0.481^{* * *}$ & 0.148 & $0.542^{* * *}$ & 0.152 \\
\hline $30-39$ yrs & 0.127 & 0.138 & 0.104 & 0.139 \\
\hline $50-62$ yrs & $0.476^{* * *}$ & 0.142 & $0.537^{* * *}$ & 0.144 \\
\hline 63 and more & $1.009^{* * *}$ & 0.185 & $0.990^{* * *}$ & 0.188 \\
\hline \multicolumn{5}{|l|}{ Interaction effects: } \\
\hline Equivalised income ${ }^{*}$ year & $-0.235^{*}$ & 0.134 & & \\
\hline Personal income*year & & & -0.109 & 0.098 \\
\hline Unemployed*year & 0.038 & 0.323 & -0.001 & 0.329 \\
\hline Disability pensioner*year & 0.143 & 0.256 & 0.184 & 0.261 \\
\hline Pensioner*year & -0.242 & 0.222 & -0.219 & 0.224 \\
\hline Student ${ }^{*}$ year & -0.342 & 0.257 & $-0.621^{*}$ & 0.343 \\
\hline Other inactive ${ }^{*}$ year & 0.234 & 0.235 & 0.204 & 0.265 \\
\hline Vocat. training ${ }^{*}$ year & 0.046 & 0.161 & 0.075 & 0.163 \\
\hline Secondary education*year & $0.299^{*}$ & 0.153 & $0.298^{*}$ & 0.156 \\
\hline Higher education*year & 0.321 & 0.204 & $0.376^{*}$ & 0.205 \\
\hline $17-29$ yrs $^{*}$ year & $0.387^{*}$ & 0.225 & $0.457^{* *}$ & 0.228 \\
\hline 30-39 yrs*year & 0.329 & 0.200 & 0.326 & 0.201 \\
\hline 50-62 yrs*year & -0.233 & 0.199 & -0.226 & 0.201 \\
\hline 63 and more ${ }^{*}$ year & -0.053 & 0.261 & 0.020 & 0.264 \\
\hline Other personal controls & Yes & & Yes & \\
\hline Year & 2.529 & 1.584 & 0.858 & 1.217 \\
\hline Constant & $-6.607^{* * *}$ & 1.135 & 0.336 & 0.879 \\
\hline
\end{tabular}




\begin{tabular}{lc|c}
\hline $\mathrm{R}^{2}$ & 0.1544 & 0.1404 \\
F ratio & 32.64 & 28.51 \\
Observations & 8932 & 8932 \\
\hline \hline
\end{tabular}

Notes: Weighted OLS regression. Pooled cross-sectional time series dataset, using two crosssectional surveys: from 1991/92 and 1997/98. Corrected for heteroscedasticity, using white estimator for variance. Dependent variable: level of satisfaction on an eleven-point scale. Year is a dummy, which takes the value of one in 1997/98.

* denotes significance at $10 \%$ level, ** denotes significance at $5 \%$ level, *** denotes significance at $1 \%$ level

Reference categories: 40-49 years, elementary education or below, employee

Other personal controls: include main and interaction effects for sex, ethnicity, region (Budapest dummy), marital status, number of children and a dummy for zero personal incomes.

Interestingly, the association between income and SWB has declined over time. In other words, the same income level brings less satisfaction. This is, however, only true for equivalised household income (adjusted for inflation). Personal income, as shown in Table 5, has a positive coefficient in the total sample, with no significant change over time. Personal income thus remained a major correlate of subjective wellbeing, unaffected by transition. What do these two apparently conflicting results suggest? The relationship between household income and individual well-being has weakened over time, assuming equal sharing within the household. This is a rather standard assumption, but may not hold. As Lundberg et al. demonstrated, people's actual consumption opportunities may differ within a family depending on their personal incomes ${ }^{4}$ (1997). The fall of employment and the declining real value of family support from the state primarily affected women and both of these are expected to reduce women's personal incomes. Declining personal incomes may have resulted less consumption for women, even in those cases where household income did not fall. The conflicting results mentioned above thus may highlight an increasing divergence between individual well-being and household resources.

4 They show that policy change in the United Kingdom, which transferred a substantial child allowance to wives in the late 1970s, had an impact on household consumption: there was a shift toward greater expenditures on women's clothing and children's clothing relative to men's clothing. This finding challenges the assumption of pooling within the household, and the assumption that only total family income affects family demand. 
Table 6: Religiosity and happiness during transition in Hungary, 1991-1998

\begin{tabular}{|c|c|c|c|c|c|c|c|c|}
\hline & \multicolumn{2}{|l|}{ All } & \multicolumn{2}{|c|}{ Religious } & \multicolumn{2}{|c|}{$\begin{array}{l}\text { Religious, excl. } \\
\text { new believers }\end{array}$} & \multicolumn{2}{|c|}{ Non-religious } \\
\hline & Coef. & Std. Err. & Coef. & Std. Err. & Coef. & Std. Err. & Coef. & Std. Err. \\
\hline Religious & $0.379^{* * *}$ & 0.099 & & & & & & \\
\hline Self-employed ${ }^{*}$ year & $0.512^{*}$ & 0.283 & -1.083 & 0.974 & -0.915 & 1.066 & $0.709^{* *}$ & 0.288 \\
\hline $\begin{array}{l}\text { Equivalised household } \\
\text { income }(\ln )\end{array}$ & $0.975^{* * *}$ & 0.094 & $0.665^{* * *}$ & 0.222 & $0713^{* * *}$ & 0236 & $1070 * * *$ & 0.104 \\
\hline Unemployed & $-1.020^{* * *}$ & 0.213 & -1.375 & 1.051 & -1.500 & 1.126 & $-0.973^{* * *}$ & 0.216 \\
\hline Disability pensioner & $-0.791^{* * *}$ & 0.197 & -0.162 & 0.395 & -0.070 & 0.410 & $-0.917^{* * *}$ & 0.227 \\
\hline Pensioner & -0.212 & 0.158 & 0.097 & 0.344 & 0.211 & 0.355 & -0.238 & 0.180 \\
\hline Self-employed & -0.282 & 0.199 & 0.465 & 0.613 & 0.351 & 0.685 & $-0.364^{*}$ & 0.209 \\
\hline Student & $1.809^{* * *}$ & 0.177 & $1.420^{* * *}$ & 0.398 & $1.555^{* * *}$ & 0.450 & $1.846^{* * *}$ & 0.197 \\
\hline Other inactive & $-0.484^{* * *}$ & 0.167 & -0.074 & 0.410 & 0.062 & 0.444 & $-0.515^{* * *}$ & 0.184 \\
\hline Vocational training & $0.370^{* * *}$ & 0.113 & 0.106 & 0.283 & 0.256 & 0.297 & $0.386^{* * *}$ & 0.124 \\
\hline Secondary education & $0.624^{* * *}$ & 0.105 & $0.852^{* * *}$ & 0.247 & $0.816^{* * *}$ & 0.268 & $0.559^{* * *}$ & 0.117 \\
\hline Higher education & $1.030^{* * *}$ & 0.136 & $1.601^{* * *}$ & 0.325 & $1.330^{* * *}$ & 0.339 & $0.870^{* * *}$ & 0.151 \\
\hline Age: $17-29$ yrs & $0.481^{* * *}$ & 0.148 & $0.825^{*}$ & 0.405 & 0.501 & 0.429 & $0.437^{* * *}$ & 0.158 \\
\hline 30-39 yrs & 0.127 & 0.138 & 0.506 & 0.403 & 0.496 & 0.427 & 0.076 & 0.146 \\
\hline $50-62$ yrs & $0.476^{* * *}$ & 0.142 & -0.070 & 0.345 & -0.237 & 0.366 & $0.594^{* * *}$ & 0.158 \\
\hline 63 and more & $1.009^{* * *}$ & 0.185 & 0.524 & 0.409 & 0.366 & 0.428 & $1.083^{* * *}$ & 0.213 \\
\hline Religious*year & -0.047 & 0.142 & & & & & & \\
\hline Equivalised income ${ }^{*}$ year & $-0.235^{*}$ & 0.134 & -0.125 & 0.319 & -0.380 & 0.334 & $-0.286^{*}$ & 0.147 \\
\hline Unemployed ${ }^{*}$ year & 0.038 & 0.323 & 1.177 & 1.220 & 1.377 & 1.282 & -0.088 & 0.339 \\
\hline Disability pensioner ${ }^{*}$ ear & 0.143 & 0.256 & -0.129 & 0.572 & -0.130 & 0.597 & 0.213 & 0.289 \\
\hline Pensioner*year & -0.242 & 0.222 & -0.592 & 0.519 & -0.656 & 0.539 & -0.188 & 0.249 \\
\hline Student ${ }^{*}$ year & -0.342 & 0.257 & -0.001 & 0.638 & -0.381 & 0.676 & -0.355 & 0.284 \\
\hline Other inactive* year & 0.234 & 0.235 & 0.139 & 0.578 & -0.133 & 0.611 & 0.229 & 0.259 \\
\hline Vocat. training ${ }^{*}$ year & 0.046 & 0.161 & 0.383 & 0.387 & 0.146 & 0.410 & 0.027 & 0.178 \\
\hline Secondary education ${ }^{*}$ year & $0.299^{*}$ & 0.153 & 0.133 & 0.353 & 0.098 & 0.380 & $0.346^{* *}$ & 0.170 \\
\hline Higher education*year & 0.321 & 0.204 & 0.170 & 0.492 & 0.416 & 0.520 & $0.416^{*}$ & 0.225 \\
\hline 17-29 yrs*year & $0.387^{*}$ & 0.225 & 0.345 & 0.587 & $1.337^{* *}$ & 0.654 & 0.399 & 0.244 \\
\hline 30-39 yrs*year & 0.329 & 0.200 & 0.600 & 0.553 & 0.928 & 0.604 & 0.288 & 0.216 \\
\hline 50-62 yrs*year & -0.233 & 0.199 & $0.944^{*}$ & 0.515 & $1.338^{* *}$ & 0.548 & $-0.438^{* *}$ & 0.218 \\
\hline 63 and more*year & -0.053 & 0.261 & $1.082^{*}$ & 0.617 & $1.430^{* *}$ & 0.652 & -0.245 & 0.295 \\
\hline Other personal controls & Yes & & Yes & & Yes & & Yes & \\
\hline Year & 2.529 & 1.584 & 0.714 & 3.727 & 3.728 & 3.914 & $3.192^{*}$ & 1.742 \\
\hline Constant & $-6.607^{* * *}$ & 1.135 & -2.439 & 2.727 & -2.808 & 2.907 & $-7.733^{* * *}$ & 1.250 \\
\hline $\mathrm{R}^{2}$ & 0.1544 & & 0.1367 & & 0.1377 & & 0.1611 & \\
\hline F ratio & 32.64 & & 6.64 & & 6.15 & & 28.56 & \\
\hline Observations & 8932 & & 1747 & & 1565 & & 7185 & \\
\hline
\end{tabular}

Notes: Weighted OLS regression. Pooled cross-sectional time series dataset, using two crosssectional surveys: from 1991/92 and 1997/98. Corrected for heteroscedasticity, using white estimator for variance. Dependent variable: level of satisfaction on an eleven-point scale. Year is a dummy, which takes the value of one in 1997/98. * denotes significance at $10 \%$ level, ${ }^{* *}$ denotes significance at $5 \%$ level, ${ }^{* * *}$ denotes significance at $1 \%$ level.

Reference categories: 40-49 years, elementary education or below, employee

Other personal controls: include main and interaction effects for sex, ethnicity, region (Budapest dummy), marital status, and number of children 
The results related to income appear counterintuitive for another reason. We could expect that in an increasingly market-oriented system people are becoming increasingly materialistic, which would strengthen the relationship between income and experienced utility. The bivariate relationship between income and life satisfaction suggests that such change was only rather modest. This relationship, however, completely disappears in the regression equations, controlling for labour market status, educational attainment and other personal characteristics. Why has income not become increasingly important in explaining people's well-being? Economic transition may have raised expectations. Many people must have hoped that the new Capitalist economic system would bring higher living standards for them. Instead of prosperity, however, they had to face recession. This implies that there may be an increasing gap between aspirations and actual income.

During economic transition average real incomes declined more than one quarter. This fall in income is expected to have a major impact on SWB. Empirical evidence from the psychological literature demonstrated that people are often more sensitive to changes in their situation relative to a reference level, rather than the absolute characteristics of the situation (see the review of Rabin 1998). They are also loss averse, valuing losses higher than gains of the same amount, and tend to be attached to objects, valuing objects higher once they possess them than before. It follows that many Hungarians may be dissatisfied with their current income levels, because they value it relative to their higher past incomes. The experience of this loss was coupled with the external environment, which was probably perceived as uncertain by many, with the appearance of unemployment, the elimination of price control and declining state transfers.

A possible further explanation for the declining association between equivalised income and SWB is that people assess their current situation relative to others. Hungarians probably increasingly assess their own situations relative to the citizens of Western Europe. Political changes brought increasing exposure to Western culture and possibilities to travel. According to a 1998 survey 11\% of the respondents say that they compare their living standards to that of Western Europeans, while only 3\% mention Eastern Europeans (Sági 2000). Unfortunately there is no similar data from the Socialist period of the country, but is seems plausible to assume that in the rather enclosed economic and social 
system Hungarians enjoyed their prosperity, the Goulash Communism, relative to other East Europeans ${ }^{5}$.

\section{Increasing ideological freedom: religion and utility}

Interestingly, religiosity was not a source of increasing satisfaction over time. The interaction effect is not significant, which implies that the relationship between religious involvement and SWB did not change over time. Contrary to the starting hypothesis, the greater social role of religious institutions did not affect church members. This may suggest personal autonomy: people's utility does not depend on the social or political power of the institution they 'belong to'. This also seems to imply that the sense of personal religious freedom was rather developed, and was well established in the constitutional changes of 1989, which reinstated religious freedom in a legal sense. Religiosity thus was not making people increasingly satisfied over time, but was a stable positive correlate of life satisfaction. The coefficient is positive and significant at $1 \%$ level. These findings confirm earlier results presented in Table 4.

In order to further analyse the relationship between religion and subjective well-being, the respondents were divided into religious and non-religious groups. I have accounted for the possible impact of 'newcomers' on the results, and estimated a separate model with their exclusion.

There are major differences between the estimated microeconometric well-being functions for the religious and non-religious social groups. As assumed in the beginning, money matters less for the religious. The association between income and happiness is weaker for those who regularly participate in religious activities compared to those who do not. The difference between the two coefficients was found significant at the $5 \%$ level. In order to try to account for possible spurious correlation, a separate model was estimated excluding those who say that they had recently became believers. The coefficient of income in this equation is still below that of the non-religious, although the difference is significant only at the $10 \%$ level. It is noteworthy that none of the labour market

5 Life satisfaction does not fully depend on comparisons, however. In his review of the literature Veenhoven powerfully demonstrates that happiness also depends on need-gratification, and as much it is so, it is not 'relative' (Veenhoven 1991). 
status variables, except the one for students, are significant for the religious group. In sum, economic variables seem to have a smaller influence on happiness among those who are religious.

Religious people seem to have largely sustained their attitudes during transition, and these were more stable than the attitudes of those who are not actively religious. None of the interaction effects of economic variables is significant for the religious group. None of the effects, which can be observed both for the total sample and the non-religious group, are prevalent, including the declining coefficient of income, the rising relative satisfaction of the self-employed and that of the highly educated. This implies that income or labour market situation is just as much, or rather just as little, associated with life satisfaction at the early point in transition than at the later one. All this suggests that religiosity as an attitude strongly determines preferences and economic choices ${ }^{6}$. Religiosity seems to provide stable preferences, thus may be a useful safeguard during the uncertainties of economic change.

\section{Conclusion}

The analysis used Hungarian survey data from an early and a later phase of economic transition, 1991-92 and 1997-98. The measure of experienced utility was general life satisfaction, a self-reported score of individual's satisfaction on a scale from 0 to 10 . The estimated microeconometric well-being equations are increasing in income and show largely similar structures to those described in the existing literature on Western Europe and the United States (e.g. Di Tella et al. 1999; Alesina et al. 2001). Unemployment and disability pensioner status, a typical way of withdrawal from the labour market in Hungary, and divorce are negatively, and high income, higher levels of education, and marriage are positively correlated with life satisfaction. There is a U-shaped pattern between age and SWB. Religious people have a consistently higher level of satisfaction.

6 A possible explanation might be based on the hypothesis that transition from socialism brought increasing materialism, partly as a consequence of greater self-reliance of individuals and partly due to increased consumption opportunities. Religious affiliation, with its smaller attachment to material values, may contribute to higher life satisfaction. Religion as a tradition may also yield more stable attitudes during economic change compared to those whose "tastes" are primarily determined by economic rationality. 
It was shown that in certain cases increasing 'ideological freedom' did not affect people, but growing 'economic freedom' did. Somewhat contrary to the starting hypothesis, the religious population was not positively affected by increasing ideological freedom. The happiness of the religious, measured as regular churchgoing, was not influenced by the expansion of the church, 'institutionalised religiosity', in social life. People, in contrast, seem to care about the growth of economic freedom. The soundest evidence on the impact of transition relates to the group of entrepreneurs. Their self-assessed well-being has increased over time. The entrepreneurs may thus be identified as major winners of the transition process.

Religiosity was shown to bring specific preferences. The paper presented empirical evidence on how religious affiliation influences people's utility and how this is exposed to economic change. People who are actively involved in religious activities have higher levels of experienced utility, seem to be less influenced by the money they have and were less affected by economic change.

The happiness equations of the religious and non-religious groups of the population significantly differ, indicating that there are attitudinal differences. To put it simply, money buys satisfaction, but not equally for all. For the religious income appears to be less of a source of satisfaction. The relationship between labour market status and SWB is also very weak among the religious group. The coefficient on unemployment, for example, is not significant. The structure of wellbeing is also more stable over time among the religious population, who seem to be less affected by the turmoil of economic transition. In sum, the determinants of happiness differ along ideological orientation. Religious people seem to have been less affected by the changes of their financial circumstances. On the contrary, however, the non-religious, especially the subgroup of entrepreneurs, appear to have benefited more from the increased opportunities of the market. 


\section{References}

Alesina, A., R. D. Tella and R. MacCulloch (2001). Inequality and happiness: are Europeans and Americans different? Harvard Institute of Economic Research. Discussion paper no. 1938. http:/ / post.economics.harvard.edu/hier/2001papers/HIER1938. pdf. Retrieved: Dec 2001.

Andorka, R. (1992). “Társadalmi változások és társadalmi problémák, 1940-1990 [Social changes and social problems, 1940-1990]." Statisztikai Szemle 70(4-5): 301-324.

Andorka, R. (1999). Dissatisfaction and alineation. A Society Transformed: Hungary in Time-Space Perspective. R. Andorka, T. Kolosi, R. Rose and G. Vukovich. Budapest, Central European University Press.

Argyle, M. (1999). Causes and correlates of happiness. Well-Being. The Foundations of Hedonic Psychology. D. Kahneman, E. Diener and N. Schwarz. New York, Russell Sage Foundation: 353-373.

Blanchflower, D. G. and R. B. Freeman (1997). "The attitudinal legacy of communist labor relations." Industrial and Labour Relations Review 50(3): 438-459.

Blanchflower, D. G., A. Oswald and A. Stutzer (2001). "Latent entrepreneurship across nations." European Economic Review 45: 680-691.

Blanchflower, D. G. and A. J. Oswald (2000). Well-being over time in Britain and the USA. NBER Working Paper 7487. Cambridge, M.A., National Bureau of Economic Research.

Clark, A. E. and A. J. Oswald (1994). "Unhappiness and unemployment." The Economic Journal 104(424): 648-659.

Di Tella, R., R. J. MacCulloch and A. J. Oswald (1999). The macroeconomics of happiness. Bonn, Centre for European Integration Studies.

Di Tella, R., R. J. MacCulloch and A. J. Oswald (2001). “Preferences over inflation and unemployment: evidence from surveys of happiness." American Economic Review 91(1): 335-341.

Diener, E. (1984). "Subjective well-being." Psychological Bulletin 95(3): 542-575.

Diener, E. and S. Oishi (2000). Money and happiness: income and subjective well-being across nations. Culture and Subjective Well- 
being. E. Diener and E. M. Suh. Cambridge, Mass., MIT Press: 185218.

Diener, E., E. M. Suh, R. E. Lucas and H. L. Smith (1999). "Subjective well-being: three decades of progress." Psychological Bulletin 125(2): 276-303.

Easterlin, R. A. (2001). "Income and happiness: towards a unified theory." The Economic Journal 111(July): 465-484.

Economic Commission for Europe (2000). Economic Survey of Europe New York, United Nations.

Ellison, C. G. (1991). "Religious involvement and subjective well-being." Journal of Health and Social Behavior 32(1): 80-99.

Freeman, R. B. (1986). Who escapes? The relation of churchgoing and other background factors to the socioeconomic performance of black male youths from inner-city tracts. The Black Youth Employment Crisis. R. B. Freeman and H. J. Holyer. Chicago, University of Chicago Press: 353-376.

Frey, B. S. and A. Stutzer (2000). "Happiness, economy and institutions." The Economic Journal 110(466): 918-938.

Hull, B. B. and F. Bold (1995). "Preaching matters: replication and extension." Journal of Economic Behavior and Organization 27: 143149.

Iannaccone, L. R. (1998). "Introduction to the economics of religion." Journal of Economic Literature 36(3): 1465-1495.

Inglehart, R., M. Basáñez and A. Menéndez Moreno (1998). Human values and beliefs : a cross-cultural sourcebook : political, religious, sexual, and economic norms in 43 societies; findings from the 1990-1993 world value survey Ann Arbor, University of Michigan Press.

Kahneman, D., P. P. Wakker and R. Sarin (1997). “Back to Bentham? Explorations of experienced utility." Quarterly Journal of Economics CXII(2): 375-406.

Kornai, J. (1994). “Transformational recession: the main causes." Journal of Comparative Economics 19(1): 39-63.

Lundberg, S. J., R. A. Pollak and T. J. Wales (1997). “Do husbands and wives pool their resources? Evidence from the United Kingdom Child Benefit." Journal of Human Resources 32(3): 463-480. 
Need, A. and G. Evans (2001). "Analysing patterns of religious participation in post-communist Eastern Europe." British Journal of Sociology 52(2): 229-248.

Rabin, M. (1998). "Psychology and economics." Journal of Economic Literature XXVI(March): 11-46.

Róbert, P. (2001). Társadalmi mobilitás. A tények és vélemények tükrében [Social Mobility. Facts and opinions] Budapest, Andorka Rudolf Társadalomtudományi Társaság - Századvég Kiadó.

Róbert, P. and E. Bukodi (2001). Entry and exit from self-employment in Hungary, in the 1980s and the 1990s. Paper presented on the spring meeting of the International Sociological Association RC 28, titled 'Expanding Markets, Welfare State Retrenchment and their Impact on Social Stratification'. Mannheim, Germany.

Rose, R. and C. Haerpfer (1998). New Democracies Barometer V: A 12Nation Survey. Glasgow, Centre for the Study of Public Policy, University of Strathclyde.

Sági, M. (2000). Az anyagi helyzettel való elégedetlenség és vonatkoztatási csoportok [Dissatisfaction with financial situation and reference groups]. Társadalmi riport [Social Report]. T. Kolosi, I. G. Tóth and G. Vukovich. Budapest, TÁRKI: 260-297.

Schumpeter, J. A. (1934). The Theory of Economic Development. An Inquiry into Profits, Capital, Credit, Interest, and the Business Cycle Cambridge, Massachusetts, Harvard University Press.

Szelenyi, I. and R. Manchin (1988). Socialist Entrepreneurs: Embourgeoisement in Rural Hungary Cambridge, Policy.

Tomka, M. and I. Harcsa (1994). A felekezeti viszonyok és a vallásgyakorlás néhány jellemzõje [Some characteristics of the denominational structure and the religious practices]. Társadalmi Riport 1994 [Social Report 1994]. R. Andorka, T. Kolosi and G. Vukovich. Budapest, TÁRKI: 396-435.

Veenhoven, R. (1991). "Is happiness relative?" Social Indicators Research 24(1): 1-34.

Veenhoven, R. (1996). "Developments in satisfaction-research." Social Indicators Research 37(1): 1-46.

WHO (2001). Suicide rates. http://www.who.int/mental_health/ Topic_Suicide/suicide1.html. Retrieved: 3 Nov 2001. 
Winkelmann, L. and R. Winkelmann (1998). "Why are the unemployed so unhappy? Evidence from panel data." Economica 65: 1-15.

World Database of Happiness. Ruut Veehoven, Erasmus University, Rotterdam. Retrieved: http://www.eur.nl/fsw/research/ happiness/. 